\title{
The Guarantees of the Human Rights of the Defendant in the Law System in Kosovo
}

\author{
Armend Podvorica ${ }^{1}$, Adelina Rakaj ${ }^{2}$ \\ ${ }^{1}$ Professor, Faculty of Law, University of Prizren “Ukshin Hoti,” Kosovo \\ ${ }^{2}$ Teaching Assistant, Faculty of Law, University of Prizren “Ukshin Hoti,” Kosovo \\ Correspondence: Adelina Rakaj, Teaching Assistant, Faculty of Law, University of Prizren “Ukshin Hoti,” Kosovo.
}

Received: September 5, 2017

doi:10.11114/ijsss.v5i11.2698

Accepted: September 25, 2017

Available online: October 13, 2017

URL: https://doi.org/10.11114/ijsss.v5i11.2698

\begin{abstract}
The paper "The guarantees of the human rights of the defendant in the law system in Kosovo" aims to treat the access of the Republic of Kosovo in the delivery of constitutional guarantees and legal guarantees to protect the defendant in the criminal procedure. Within these guarantees, special emphasis is placed on the judicious acts in force that provide these guarantees in the Republic of Kosovo. A special analysis with regard to this paper is dedicated to the Convention for the Protection of Human Rights and Fundamental Freedoms (ECHR), the practice of European Court of Human Rights (ECtHR), the Constitution of the Republic of Kosovo and the Criminal Procedure Code of Kosovo (CPCK). The analysis of those acts clarifies that the guarantees of the Legal System in Kosovo coincide with the rights of the defendant.

Another dimension that finds space within the paper is the practical implementation of the guarantees provided by the aforementioned acts in terms of the rights of the defendant. The role of the Constitutional Court in the Republic of Kosovo in the past and now has been mainly analyzed in the formation of the constitutional and international guarantees, applicable in Kosovo concerning the rights of the defendant in the criminal procedure.
\end{abstract}

Keywords: the rights of the defendant, criminal procedure, guarantees, ECHR, ECtHR, constitution, legal system

\section{Introduction}

The legal position of the defendant in the criminal procedure unless it is a theoretical issue which is treated in the penal procedure, it is also an issue which is adjusted to international, constitutional and legal acts. This means that the guarantees of the rights of the defendant do not just belong to the national law but also to the international law. The status and the rights of the defendant in the legal system in the Republic of Kosovo will be crucially analyzed in this paper, in order, to have an overview of the kind of guarantees that the legal acts in Kosovo offer about the rights of the defendant.

Considering this topic, the paper will be treated in two sections. In the first section, constitutional and legal guarantees offered by the Republic of Kosovo involving the improvement of the defendant rights will be discussed, whereas; the second part will deal with the standards that have been de veloped in the Republic of Kosovo to implement defendant rights.

Within the framework of these standards, the established standards are implied as a result of the implementation of legal guarantees provided by the legal order of the Republic of Kosovo, so this includes the decisions of the Regular Courts, the decisions of Constitutional Court and the standards established by the decisions of the Court of Human Rights (ECHR).

\section{General Views Regarding the Defendant Rights in the Republic of Kosovo}

Before discussing the rights of the defendant in relation to legal guarantees in the Republic of Kosovo, the notion of "defendant" should be clarified so that the reader can understand the arguments better. The defendant is the person to whom criminal proceedings are initiated, so the term "defendant" has a threefold meaning, which is used for the defendant, the accused and the convict (Sahiti \& Murati, 2016, p.157). In addition to those three subjects, the rights of the defendant are also valid for the arrested person who may be suspected and to whom the investigation and accusation process may be initiated, this is mentioned by the Criminal Procedure Code of the Republic of Kosovo.(See for more: Flynn, Hodgson, Mcculloch, \& Naylor, 2016, p.227). 
In relation to the notion of the defendant, the Criminal Procedure Code defines it as: "the defendant is the person against whom the criminal procedure applies." Also, in this code, the term "defendant" is used as a general phrase for the "defendant", "the accused" and "the convict." (Code no. 04 / L-123 of the Criminal Procedure, 28 December 2012, Article 19).

Based on what has been said above, the legal order in the Republic of Kosovo offers three legal bases of the relationship to the guarantees of the defendant rights which are:

1. Applicable international acts in the Republic of Kosovo and judicial practice of the ECtHR;

2. The Constitution of the Republic of Kosovo and judicial practice of the Constitutional Court;

3. The applicable penal code;

Regarding the international acts that are applicable to the Republic of Kosovo and which guarantee some of the rights of the defendant, the Republic of Kosovo represents the model of states which have offered a very advanced position of international acts within the internal legal order.

The Constitution of the Republic of Kosovo (article 22, 2008) defines that some of the international instruments which guarantee the rights of the defendant are directly applicable to the Republic of Kosovo. Based on the statues that international acts have, according to the article 22 of the Constitution of the Republic of Kosovo, it is implied that those have priority in contact with other legal acts which means that their validity in the legal order in the Republic of Kosovo is direct because the Republic of Kosovo has established those conventions through constitution and they are considered part of the inside legal order and in the aspect of hierarchy they are more powerful than laws.

If we start from the principle of direct implementation of international acts contained in Article 22 of the Constitution of the Republic of Kosovo, as long as these acts regulate the rights of the defendant, they also provide guarantees of the respect for these rights in the Republic of Kosovo (Morina, Korenica \& Doli, 2011, p.294).

Two of the most important acts that are part of the international instruments, article number 22 of the Republic of Kosovo concerning defendant rights are European Convention for the Protection of Human Rights (ECHR) and its Protocols and International Covenant on Civil and Political Rights (ICCPR) and its Protocols.

\section{The Guarantees that ECHR and ICCPR Offer; the Standards Created by ECtHR and Their Status in the Republic of Kosovo}

As it was mentioned above the ECHR is among the acts which are directly applied in the Republic of Kosovo and offer a large number of rights for the defendant.

ECHR (1950) in article number 5 and 6 refers to some of the rights pertaining to the defendant, involving also the arrested, the accused and the convict.

In the article number 5 of ECHR (the right to freedom and security) are adjusted to the rights of the arrested as a defendant person in criminal procedure. Likewise, in this article, paragraph number 2 states, "everyone who is arrested shall be informed promptly, in a language which he or she understands, of the reasons for his arrest and of any charge against him." Also, the authorities that apply this law according to this article, paragraph 3, should send the arrested person before the judicial authority in a very short period of time to deal with the reasons for his arrest. Moreover, this should also be understood as a right of the arrested person to be heard within a reasonable time before a competent judicial authority.

Also, ECHR in the article number 6 adjusts the rights of the accused as the rights of the defendant, to have the right to a fair trial. Among the principles in the article number 6, paragraph 2, is that every accused person is presumed innocent until one is legally proved guilty. According to the ECHR (article 6.3, paragraphs a, b, c, d), the rights of the accused as a defendant in the criminal procedure are: to be informed promptly, in a language which he understands and in detail, of the nature and cause of the accusation against him; to have adequate time and facilities for the preparation of his defence; to defend himself in person or through legal assistance of his own choosing or, if he has not sufficient means to pay for legal assistance, to be given it free when the interests of justice so require; to examine or have examined witnesses against him and to obtain the attendance and examination of witnesses on his behalf under the same conditions as witnesses against him. Furthermore, this article does also give importance to the right of the accused person for an interpreter in case one does not speak that language. Even, Van der Vlis (2010, p. 30) adds that in a criminal trial, the judge will have to assess every time whether or not the assistance of an interpreter is required, and if so, whether the quality of the performance of that interpreter is deemed adequate. Aside the guarantees which were aforementioned, the right for legal tools has been taken into consideration as well. According to the Protocol No. 7 in European Convention for the Protection of Human Rights and Fundamental Freedoms (1984, article 2), each defendant pronounced guilty in the first instance has the right to submit his / her review again to a court of another degree.

One of the most important rights of the defendant in the criminal process in the context of Article 6 of the ECHR is the 
right to protection. As stated above, a person's pre-trial detention (custody) procedures are the most important stages of the violation of the rights of the defendant, in particular, the right to have protection in this context, the absence of the defense counsel in pre-trial proceedings, greatly influences in some aspects such as: puts the accused in an unequal position; affects the ability of a lawyer to negotiate and prepare the case as well as hinder other efforts to negotiate the agreement of being pleas of guilty and the acceptance of pleas of guilty at the earliest stages of the procedure (Flynn et al., 2016, p.227).

In addition to the ECHR, one of the acts that applies directly to the Republic of Kosovo and contains provisions regarding the rights of the defendant is also ICCPR. According to the International Covenant on Civil and Political Rights (adopted on 16 December 1966, Article 14), almost the same principles as set out in Article 6 of the ECHR are embodied also within the ICCPR. Thus, a comparison between Article 6 of the ECHR and Article 14 of the ICCPR provides that both of these acts guarantee the same rights in the same spirit.

Given the fact that the rights of the defendant are part of international acts, such as the ECHR, in this context, in relatio n to the rights of the defendant, the ECtHR has established practice through its cases. Thus, in the case of Brozicek v. Italy (19 December 1989, p. 12), he stated "even though the indictment was filed, but the fact that the defendant was not of Italian origin and did not have a residence in Italy, informed the Italian authorities on a clear way, telling them that he had difficulty in understanding the contents of this communication for linguistic reasons and he requested it to use his mother tongue or one of the official languages of the United Nations." Failure to comply with this request by the Italian authorities was considered to have prevented the defendant from being notified of the content of his indictment and this was considered a violation of Article 6.3 (a) of the ECHR.

In the case of Mattoccia v. Italy (25 July 2000) among others, the ECtHR noted that the information that constituted the indictment was unclear, such as details of the place and time of the commission of the offense, where this has affected its right to prepare the defense. In the other case, Sadak and others against Turkey (11 June 2002) among others, the ECtHR emphasizes the fact that the factual retraining of the facts requires Ankara's National Security Court to give the defendants the opportunity to exercise their protection in a practical and effective manner, especially by giving them the time needed to prepare the defense.

Among other things, the ECtHR, in the spirit of the ECHR, has also dealt with certain cases concerning the right to a trial in a reasonable time. As stated above, this is one of the guarantees provided by the ECHR, which has been largely addressed by the ECtHR. In the case of Kuppinger v. Germany (no.62198 / 11, 2015, p. 6), the Court assessed as follows "that the length of proceedings before the District Court of Frankfurt, which lasted from 19 May 2005 to 22 March 2010, has violated the applicant's right to a trial within a reasonable time under Article 6.1 of the Convention".

In view of this, as stated above, the Republic of Kosovo has taken over the direct implementation of international acts (in this case ECHR and ICCPR). Also, the Republic of Kosovo, although not an active part of the ECtHR because it is not part of the Council of Europe, has taken over the implementation of the ECtHR practice (Constitution of Kosovo, Article 53). This means that in the case of deployment courts and other institutions, such as the State Prosecutor, the Police etc., have a constitutional obligation to respect the ECHR's spirit as well as the case law of ECtHR in handling the cases in order to avoid and minimize possible violations of the defendant's rights in the proceedings.

\section{Guarantees Providing the Internal Acts of the Republic of Kosovo with Regard to the Rights of the Defendant}

The Constitution of the Republic of Kosovo, in conformity with Article 22, except that it makes applicable the ECHR and ICCPR, also in Chapter II, in particular guarantees the rights of the defendant, wholly in the spirit of the ECHR and ICCPR.

Thus, Article 29 and Article 30, the Constitution of the Republic of Kosovo guarantees the rights of the arrested person as well as the rights of the accused. Therefore, according to the Constitution of the Republic of Kosovo (2008, Article 29, paragraph 2), regarding the rights of the arrested states that: "everyone who is deprived of liberty shall be promptly informed, in a language he/she understands, of the reasons of deprivation. The written notice on the reasons of deprivation shall be provided as soon as possible." Article 29.3 of the Constitution of Kosovo guarantees the right of silence of the defendant as well as his/her right to elect the defense counsel as one wishes. According to Etienne (2004, p.428), the rights of defendants in the proceedings depend not only on the judicial knowledge of these rights but also on the willingness of lawyers to protect these rights. Therefore, the right to choose a defense attorney is of great importance and also affects the realization of other rights attributed to the defendant.

Also, the Constitution of the Republic of Kosovo (Article 29, paragraphs 4 and 5) guarantees the remedies of the arrested person, in the capacity of the defendant, as well as the right to compensation for unfair deprivation of liberty. The context of guaranteeing the right to legal remedies, in the spirit of the Constitution of the Republic of Kosovo, means that remedies are effective. In the Mifsud v. France case (No.57220 / 00, 2002, p.5), the ECtHR has provided the definition of the effectiveness of remedies and that: "a remedy is effective if it can be used or expedited to take a decision from the courts that consider the 
case, or to provide the litigants with an appropriate address for the delays that have already occurred."

The articles 30 and 31 of the Constitution of the Republic of Kosovo define the rights of the accused as follows: (1) to be promptly informed, in a language that she/he understands, of the nature and cause of the accusation against him/her; (2) to be promptly informed of her/his rights according to law; (3) to have adequate time, facilities and remedies for the preparation of his/her defense; (4) to have free assistance of an interpreter if she/he cannot understand or speak the language used in court; (5) to have assistance of legal counsel of his/her choosing, to freely communicate with counsel and if she/he does not have sufficient means, to be provided free counsel; (6) to not be forced to testify against oneself or admit one's guilt. Also, the Constitution of the Republic of Kosovo guarantees the right to a fair and impartial trial and the right to a reasonable trial, a right embodied in the ECtHR practice.

The Constitution of the Republic of Kosovo (Article 29), within the rights of the defendant, also provides for the right to liberty and security, which means that no one can be deprived of liberty except in cases foreseen by law and after a decision of the competent court.

Undoubtedly, all the guarantees provided by the Constitution of the Republic of Kosovo, in terms of the rights of the defendant, are in line with the international acts and standards enshrined in the ECHR and in the ECtHR practice. Such a thing can be seen in the spirit of Chapter II of the Constitution of the Republic of Kosovo.

\subsection{Guarantees and Standards Implemented by the CPCK}

In addition to the Constitution, an important basis to guarantee the rights of the defendant in the Republic of Kosovo is the Criminal Procedure Code of Kosovo (CPCK). In CPCK, the position of the defendant in criminal proceedings is regulated in two ways, and it is by the principles of criminal procedure and taxation through the counting of the defendant's rights, which are not in principle form.

According to the CPCK, procedural principles that reflect the position of the defendant are: The presumption of the defendant's innocence and the principle In Dubio Pro Reo (Article 3), Ne Bis in Idem (Article 4), Equality of Parties (Article 9), Publicity of the main trial (Article 293) and the principle Reformatio in Peius (Article 395), while the rights of the defendants laid down in the CPCK are: The right to fair and impartial trial within a reasonable time (Article 5), Notification on the Reasons for the Charges, Prohibition against Self-incrimination and Prohibition against Forced Confession (Article 10), Adequacy of Defence (Article 11), the right of defendants to translation (Article 14), the right to legal remedies; as discussed above, these rights are defined in international instruments and in the Constitution of the Republic of Kosovo.

The presumption of innocence of the defendant, as a fundamental principle of the proceedings, directly reflects on the position of the defendant in criminal proceedings where the defendant is considered innocent until his guilt is confirmed by a final judgment.

According to Mahoney (2004, p. 120), the presumption of innocence constitutes an essential guarantee for the defendant's position in the proceedings because the burden of proof is transferred to the prosecutor and allows the defendant to benefit from the suspicion. Of course, the incorporation of this principle is a guarantee for the legal position of the defendant and excludes the possibilities for the prejudice of the case and at the same time in correlation with other principles ensures the equal standing of the defendant with the state prosecutor as a procedural subject.

The principle of Right to Fair and Impartial Trial within a Reasonable Time (Article 5) is also a basic principle which is a reflection of Article 6 of the ECHR, respectively the right to a fair trial. By this principle, the legal base is created for respecting the rights of the defendant by creating an obligation for professional and objective judgment. The right to a fair trial is not dealt within the courts in the sense of its violation, because the right to a fair trial or a fair trial may be violated by any public authority or public institution. (See for example: Constitutional Court of Kosovo, Cases KI99 / 14 and KI100 / 14, Applicants Shyqyri Syla and Laura Pula, paragraph 77).

However, in our case, the right to a fair trial is dealt with within the framework of its application by the courts in a criminal case. So, according to Leanza \& Pridal (2014, p.4), a judge cannot make a fair decision if it is considered that there has been a serious violation of the right to a fair trial. Such a decision would be considered a fundamental violation of the rights of the defendant in the proceedings.

The right to a trial within a reasonable time, as part of this article, is the obligation of the court to conduct the procedure without delay.

According to Mahoney (2004), to assess whether the trial was done within a reasonable deadline, the time from the indictment to the imposition of the sentence, including the appeal procedure, should be calculated.

In order to realize the principle of trial within a reasonable time CPCK (2013, Article 314), aside the definition of this right, in a separate article it stipulates the length of the judicial review by setting out preclusive legal deadlines, where if 
the main trial is before a single trial judge, the main trial shall be completed within ninety (90) day, or within one hundred and twenty (120) days if the main trial is before a trial panel, while cases are counted in a taxable manner, when the continuation of the main trial may be required for another thirty (30) days, such as the number of witnesses, the enormous number of evidence, the lengthy evidence and the security of trial review.

Undoubtedly, the clear regulation of deadlines for the completion of the main trial provides greater assurance for the defendant's right to a trial within a reasonable time and excludes the possibility of judicial bodies to neglect matters and to delay the proceedings.

Also, cases where the defendant is in detention, respectively in detention on remand, present an urgent procedure, defining the legal deadlines for the duration of these measures. However, it is apparent from the judicial practice that in the Republic of Kosovo the judges have been shown to be too "clumsy" in terms of the implementation of the time limits set by the CPCK in order to realize the right to a reasonable trial. Among other things, in order to have a proper implementation of the trial in a reasonable time, lawyers and judges should address some of the obstacles to timely judgment in order to take their role seriously for the implementation of this right. (Holland, April 14, 2015, p.40)

Publicity of the main trial (CPCK, Article 293), also constitutes a fundamental principle of the criminal procedure, which is also a guarantee for a fair and objective judicial process. According to Amar (1996, p.680), this principle, amongst others, has a great importance in informing the public about the victory of truth at trial; a public trial would protect innocence but would make life more difficult for the guilty.

\section{Implementation of Guarantees for the Rights of the Defendant in the Republic of Kosovo and the Role of the Constitutional Court in this Process}

The context of enforcing guarantees regarding the rights of the defendant, defined in the international acts, the Constitution or the Criminal Procedure Code of the Republic of Kosovo are one of the most important challenges of Kosovo's legal system.

The defendant's right to protection as a fundamental right and the fulfillment of this right is rarely done, except in cases where the defendant is in the list of cases of mandatory defense prescribed by the CPCK (Article 57, defense counsel in defense cases CPCK No. 04 / L-123, 13 December 2012), therefore, this means that the CPCK makes exceptions to the obligation of appointing defense counsel to the defendants.

In the context of the obligation, the ECHR and the ECtHR have installed the same standards, creating constraints. Thus, in the case of Quaranta v. Switzerland (May 24, 1991), the ECtHR, by interpreting the ECHR, has established three standards regarding the right to compulsory defense, whereby three criteria must be taken into consideration: seriousness of the offense and punishment, the complexity of the offense as well as the ability of the accused to provide representation. Nevertheless, out of 216 cases monitored by the OSCE team (June 2016, pg. 8), in the courts of the Republic of Kosovo during January 2014 and June 2015, 137 cases were not represented by public advocates at public expense, in only 11 of these reviews the defendant was assigned to a defender according to official duty, while the remaining 68 judicial remarks, the defendants decided to engage defense counsel at their own expense.

It has also been noted in many cases that in court hearings the judges did not inform the defendant of their rights or even if they did so, they did not make it explicitly, where such an obligation of the judges is foreseen in Article 246 (1) and CPCK (OSCE, June 2016, p.11).

This fact of non-disclosure has resulted in a violation of the defendant's right to a defense. The lack of defense counsel, according to the OSCE report (2016, p.12-13), for the defendants who were unable to pay it, had a direct impact on the quality of their defense and consequently on the issue of evidence because the majority of defendants did not have knowledge of legal matters, while this issue directly affected the final issue in criminal proceedings. Also, according to Kremens (2011, p.14), "this right has been designed to protect the accused from harm that may be done to him by 'inhumane' legal mechanisms."

Violations of the rights of the defendant in the investigation and in the rising of indictment have also been identified in a Report of the Ombudsman in the Republic of Kosovo, drawn up after the complaint of some citizens (Case Halili et al., No.564 / 2016) where the Kosovo Special Prosecution Office failed to enforce the warrant for the defendant to inform them of the indictment, because the same ones for the indictment were reported through the media. (The guarantee for informing the accused, for filing the indictment is set forth in the ECHR Article 6 as well as in the Constitution of the Republic of Kosovo 2008, Article 31).

In this case, it should be borne in mind that timely notification of the indictment is not only a formal obligation but an obligation that must be fulfilled, since this may also affect other issues, in particular, the effective defense by the defendant. As a result, the effective defense of the defendant plays an important role in the equality of parties in the proceedings. 
According to the Ombudsman's arguments, failure to inform on time, as in the present case, automatically reduced the defendant's position in the proceedings and violated the principle of equality of the parties because the defendants were not made available in time for the evidence and could not prepare his defense (Halili Report and others, No.564 / 2016, paragraph 18). According to the CPCK (Article 233), informing late the defendant and that through the media, as in the concrete case, could have affected the defendant's right to negotiate the plea agreement and the right to be a cooperative witness (Article 235).

In the judicial practice of the Republic of Kosovo, the regular courts have largely failed to apply the constitutional standards as well as those of the ECHR and ECtHR. This failure has often resulted in violations of the rights to the proceedings, especially the right to a fair trial. Such a contention for a violation, or rather a correction of the work of regular courts, has been done on several occasions by the Constitutional Court of Kosovo.

The Constitutional Court of Kosovo (Applicant Shefqet Berisha, case No. KI31 / 17, paragraph 77) found that the regular courts in the Republic of Kosovo violated the principle of equality of arms and the right to a fair trial under Article 31 of the Constitution and Article 6.1 of the ECHR, because in all instances they have failed to take into account the evidence and witnesses proposed by the applicant. Among other things, in this case, the standard is set that judges in regular proceedings should pay attention to the constitutional provisions, respectively Articles 22 (Direct Implementation of International Agreements and Instruments) and 53 (Interpretation of Human Rights Provisions) of the Constitution.

The legal provisions should be interpreted in the spirit of the Constitution of Kosovo and the ECHR. In this light, the Constitutional Court of Kosovo (Case No. KI31 / 17, paragraph 107) considers that, without considering the evidence presented by the State Prosecutor, the Supreme Court has not interpreted and applied the law in the spirit of the Constitution and of the Convention.

The right to a fair trial requires judges to be cautious, as they are always in danger of violating the right. Indeed, the right to a fair trial is a general reference to a complex of other rights such as the right to access to the courts, the right to present arguments and evidence, the principles of adversity and equality of arms. (Judgment, case no. KI10 / 14, Applicant: Raiffeisen Bank Kosovo SH.A., paragraph 39).

In case no. K178 / 12 (Applicant Bajrush Xhemajli, paragraph 106), the Constitutional Court ruled that the regular courts in the Republic of Kosovo have violated the right to a fair trial because of the fact that the regular courts have failed to allow the claims lodged by the party. Such a violation violated the rights of the defense and the fairness of the proceedings as well as depriving the applicant of the opportunity to submit additional arguments to the court. In most cases of the Constitutional Court of Kosovo, it is noted that they have been completed, mainly by violating the standards of the right to a fair trial, according to Article 31 of the Constitution and Article 6.1 of the ECHR. All the criminal arguments and criminal offenses that have occurred to the party were finally judged by the court as a violation of the right to a fair trial, which is closely related to all the principles of criminal procedure.

\section{Conclusion}

Undoubtedly, from the abovementioned treatment, it is clear that Kosovo's Legal System offers a lot of guarantees regarding the rights of the defendant in criminal proceedings. Among the main guarantees are the ECHR norms and ECtHR practice, which the Republic of Kosovo has undertaken to implement directly (without ratification). The Constitution and the Criminal Procedure Code of the Republic of Kosovo are quite advanced in terms of the guarantees for the rights of the defendent, even in this dimension, they are fully drafted in the spirit of the ECHR and the Constitution.

An important advantage of the Juridical System of the Republic of Kosovo with regard to guarantees for the rights of the defendant remains the direct application of the ECHR provisions and the ECtHR's practice since such an obligation derives from the constitution.

Although the Republic of Kosovo's Juridicial System is very advanced in this respect, the implementation of the ECHR provisions and the ECtHR's practice by the regular courts, regarding the guarantee of the rights of the defendant, remains a concern.

In the case of the regular courts in the Republic of Kosovo, no case can be found where judges have directly applied the provisions of the ECHR or any case of ECtHR regarding the rights of the defendant.

This fact is a very worrying element, given the constitutional status of the ECHR and the ECtHR's practice in the Republic of Kosovo.

One such circumstance of non-implementation of the ECHR and the case law of the ECtHR, regarding the rights of the defendant, has activated the Constitutional Court of the Republic of Kosovo which through its final judgments has compensated for the omissions made by the regular courts in the enforcement standards of the ECHR. Although no special reason can be found, why regular courts in the Republic of Kosovo do not directly apply the ECHR standards, it can be the 
large number of cases brought to court, which has caused considerable delays in the settlement of cases and that automatically results in a violation of the right to a reasonable trial.

Although with a privileged status of the ECHR and the practice of the ECtHR as well as with highly progressive constitutional and legal provisions regarding the rights of defendants in criminal proceedings, Kosovo has failed to sufficiently apply these standards. One determining factor in this regard is the inability of Kosovo to be an active part of the ECtHR since it is not yet a member of the Council of Europe. Only after Kosovo becomes a member of this mechanism will it be possible to notice the level of implementation of the guarantees of the defendant's rights in criminal proceedings, as these guarantees will be treated in the light of the ECtHR, where Kosovo will be potentially a party indicted by citizens (defendants) to whom the rights in criminal proceedings are violated.

\section{References}

Amar, A. R. (1996). Foreword: Sixth Amendment First Principle. Faculty Scholarship Series, Paper 937. THE Georgetown Law Journal, 84, 64.

Etienne, M. (2004). The Declining Utility of the Right to Counsel in Federal Criminal Courts: An Empirical Study on the Diminished Role of Defense Attorney Advocacy Under the Sentencing Guidelines. California Law Review, 92(2), 427-485.

Flynn, A., Hodgon, J., Mcculloch, J., \& Naylor, B. (2016). Legal aid and access to legal representation: Redefining the right to a fair trial. Melbourne University Law Review, 40(1), 207-239.

Leanza, P., \&Pridal, O. A. (2014). The right to a fair trial: Article 6 of the European Convention on Human Rights. Alphen aan den Rijn, The Netherlands: Wolters Kluwer Law \& Business: Kluwer Law International.

Kremens, K. (2011). The protection of the accused in international criminal law according to the human rights law standard. Wroclaw Review of Law, Administration \& Economics, 1(2)

Mahoney, P. (2004). Right To A Fair Trial In Criminal Matters Under 107 Article 6 E.C.H.R. Judicial Studies Institute Journal, 4(2). access date: 16.07.2017.

Morina, V., Korenica, F., \& Doli, D. (2011). The relationship between international law and national law in the case of Kosovo: A constitutional perspective, I•CON (2011), 9(1), 274-296.

Sahiti, E., \& Murati, R. (2016). Criminal Procedure Law. Prishtinë.

Van der Vlis, E. J. (2010). The right to interpretation and translation in criminal proceedings. The Journal of Specialized Translation, 14

\section{Other Documents:}

Case of Brozieck v. Italy (Application No. 10964/84), Judgment Strasbourg, 19 December 1989.

Case of Kuppinger v. Germany (Application no.62198 / 11), Judgment Strasbourg, 15.01.2015.

Case of Mattoccia v. Italy (Application No. 23969/94), Judgment Strasbourg, 25 July 2000.

Case of Misfud v. France (Application No. 57220/00). Judgment Strasbourg, 11 September 2002

Case of Quaranta v. Switzerland (Application no.12744 / 87), Judgment Strasbourg, 24 May 1991.

Case of Sadak and Others v. Turkey (No.2) (Application No. 25144/94, 26149/95 to 26154/95, 27100/95 and 27101/95), Judgment Strasbourg, 11 June 2002.

Constitution of the Republic of Kosovo, 2008.

Criminal No. 04 / L-123 of the Criminal Procedure Code, 28 December 2012, Prishtinë.

European Convention on Human Rights, Rome, 4.XI.1950.

International Covenant on Civil and Political Rights. Adopted and opened for signature, ratification and accession by General Assembly resolution 2200A(XXI) of 16 December 1966.

Judgment in Case No. KI10 / 14, Applicant Joint Stock Company Raiffeisen Bank Kosovo SH. A

Judgment in Case No. KI31 / 17, Applicants Shefqet Berisha, Constitutional Court of the Republic of Kosovo.

Judgment in Case No. Kl78 / 12, Applicant Bajrush Xhemajli, Constitutional Court of the Republic of Kosovo.

Judgment in Cases No. KI99 / 14 and KI100 / 14, Applicant Shyqyri Syla and Laura Pula, Constitutional Court of the Republic of Kosovo.

Protocol No. 7 to the Convention for the Protection of Human Rights and Fundamental Freedoms, Strasbourg, 22.XI.1984, 
Article 2.

Report with Recommendations of the Ombudsperson of the Republic of Kosovo, Rasti Halili and others, No.564 / 2016. Review of the Implementation of the New Criminal Procedure Code of Kosovo - June 2016.

\section{Copyrights}

Copyright for this article is retained by the author(s), with first publication rights granted to the journal.

This is an open-access article distributed under the terms and conditions of the Creative Commons Attribution license which permits unrestricted use, distribution, and reproduction in any medium, provided the original work is properly cited. 